\title{
GOLPH3 Gene
}

National Cancer Institute

\section{Source}

National Cancer Institute. GOLPH3 Gene. NCI Thesaurus. Code C122037.

This gene is involved in cellular trafficking and Golgi shape. 